\title{
The revival of the Byzantium through early twentieth century domestic collections in Greece: tradition, modernity and gender
}

\author{
Alexandra Bounia
}

\begin{abstract}
Between the two world wars, affluent and intellectual men and women in Greece assembled and displayed in their private homes in Athens collections of Byzantine and pseudo-Byzantine objects in order to recreate personal renderings of the 'Byzantine world'. Some of these collections, like the one by Dionysios Loverdos, ultimately transformed into house museums; others, like the collection owned by Eleni Stathatos, were donated to institutions where they are exhibited to this day; finally, a few, like the one by Eleni Kanellopoulou-Zouzoula, were dispersed and disappeared once their owners passed away. In this paper, I discuss these collections and their development against the backdrop of the Byzantine revival in Greece and the support and promotion of Byzantium and its art by the Arts and Crafts movement in Britain. I focus on these collections as interior decoration; the appreciation and understanding these collections enjoyed, which varied according to the gender of the collector; and the changes in meaning as these collections went from the domestic to the institutional.
\end{abstract}

Keywords: Byzantine collections, domestic museums, gender, Greece, Middle Ages

\section{Introduction}

In the period between the two world wars, a number of Byzantine or pseudo-Byzantine collections were assembled and displayed in private dwellings in Athens, Greece. These collections consisted not just of objects; they were artistic interiors, 'salons', used not just to create living spaces for their owners and to display artefacts, but also to make claims regarding the identity of the home owner and his or her aspirations on a private and public level. This identity was structured around ideas of tradition and authenticity, nostalgia and nationalism. Some of these collections eventually developed into private museums, others remained in the private realm and they either disappeared once their owners, mostly women of the upper class, died, or were transferred to museums, where they are still exhibited.

This paper aims to explore these collections and discuss them in light of Greece's Byzantine revival at the end of the nineteenth century, as well as its relation to the British Arts and Crafts movement. Almost at the same time as it was being 're-discovered' in Greece, Byzantium was also enjoying its first rise in popularity in Britain through the Arts and Crafts movement. ${ }^{1}$ It was connected to modernism and the avant-garde in the arts, ideas that were expressed through intellectuals such as John Ruskin or William Morris. In this paper, I argue that in Greece, as in Britain, where the Ruskinian museum ideology developed, Byzantine salons assembled in the interwar period served Ruskinian principles: they put emphasis on salvage museology, they followed the trend of the Byzantine revival and thus served the purposes of modernism, all the while paradoxically expressing nostalgia for the authenticity of folk art. Furthermore, they operated beyond archaeological facts to create alternative worlds for the individuals collecting them and 
for Greek society. These assemblages did not even conform to archaeological standards - since the objects were not necessarily Byzantine - but were used to contribute to a mythical (mytho-poetic) construction of the nation and the understanding of the 'self'.

The following sections will focus on Greece's Byzantine revival and its role in the Arts and Crafts movement in Britain. I will then discuss Byzantine parlours, before focusing on the national and gendered perspectives that these collections/displays brought to the fore regarding their owners' identity and role in the public realm.

\section{The Byzantine revival in Greece}

The reception of Byzantium has not been studied to the same extent and depth as that of classical antiquity, despite the fact that the 'desire' for Byzantium and its influence has been persistent through the years. ${ }^{2}$ After the fall of Constantinople in 1453, there was an effort in Italy to collect and transcribe Byzantine Greek texts, indicating an interest in Byzantine history and its cultural production. This interest soon spread to places like Augsburg (in Austria), Leiden and Paris, and the rest of Europe. ${ }^{3}$ Another crest in interest was seen in the eighteenth century within the frame of Romanticism and the emergence of nationalist and religious movements, especially in Western Europe. ${ }^{4}$ In the parts of Southeast Europe that belonged to the Ottoman Empire however, this interest came slightly later, mostly in connection with the construction of national identities during the empire's decline towards the end of the eighteenth century. ${ }^{5}$ In Greece, interest in the Byzantine past is usually considered to start in the 1840s, and grow towards the end of the nineteenth century and the first quarter of the twentieth. ${ }^{6}$ This delay, compared to other parts of Europe, is due to the specific circumstances of Greece: from the start of the eighteenth century, it was classical antiquity that held centre stage amongst philhellenes, especially as a tool to attract support for the Greek uprising in the 1820s and the establishment of the modern Greek state in 1830. Up until the first half of the nineteenth century, Greek intelligentsia continued to reject historical eras other than the ancient past, which they considered the sole historical component the country needed for its modern development. ${ }^{7}$ According to Liakos, ${ }^{8}$ the eventual inclusion of the Byzantine period in the national story points to a major transition in terms of how the past was constructed and understood:

... [I]t illustrates the transition from one mental structure of historical imagination to another: from the schema of revival, that acknowledged the classical Greek past as the immediate predecessor of modern Greece, to the schema of continuity, that supported a linear, although not without obstacles, path from antiquity, through Byzantium and the Ottoman period to that present day. ${ }^{9}$

This great mental change is connected to the Romantic period of Greek historiography, ${ }^{10}$ which is also associated with territorial expansion and irredentist politics, i.e. what came to be known as the 'Great Idea': a vision of a 'large Greece' bringing together the 'Hellenic nation' regardless of state borders. ${ }^{11}$ In historiographical terms, it was the work 
of Spyridon Zambelios (1815-1881) and Konstantinos Paparrigopoulos (1815-1891) that brought these ideas together and created a Romantic national history of continuity. ${ }^{12}$

Paparrigopoulos, often called Greece's 'national historian', published his monumental, multi-volume work entitled History of the Greek Nation between 1860 and 1874. Based on the tripartite division of historical periods suggested by Zambelios (i.e. ancient, medieval, modern), he created a 'grand narrative' for the Greek (Hellenic) nation, which was ultimately adopted by the Modern Greek state, and persists to this day. It is a story of continuity and perseverance; an uninterrupted transition of Greek people across historical periods. ${ }^{13}$ In presenting the Byzantine past as an integral 'step' in the continuous story of the Greeks, Paparrigopoulos changed the meaning of national identity and, in an almost revolutionary way, transformed the national self from one that had been imposed on Greece by European classicism to one that was produced locally and included other aspects of identity and the past. ${ }^{14}$ However, this national self maintained a very clear proWestern basis: Paparrigopoulos wanted to inscribe Greek history into the European one. In other words, he wanted to depart from Zambelios' earlier understanding that connected Byzantium to the Patriarchate, the Church and the Byzantine emperors, and bring it closer to the 'Western' approach, which included notions of 'progress' and 'secularisation'. ${ }^{15}$

Paparrigopoulos introduced a new style in writing national historiography: instead of using the third person, he initiated the use of 'we' and 'us', in describing the Greeks of the past. This choice marks a shift in emphasis in terms of writing, in the sense that this was not done from the outside looking in anymore. The nationals ('We') were writing the story of themselves, instead of Western philhellenes ('Them') presenting the history of the Greek nation through their lens. This, along with the 'quest' for authenticity that arose with the interest in the life of 'ordinary' people, stemmed from the Romantic tradition and formed integral parts of the process of 'nationalisation'. ${ }^{16}$ Consequently, this process of re-writing the national story and appropriating parts of the past that were not previously included, in order to explore the 'real self', attracted the attention of the intellectual elites of the country and initiated a series of developments, not only on the level of historiography, but also on other levels of cultural and intellectual production, such as literature, philology, architecture, visual arts, music, and so on.

Naturally, the process of appropriating the past for the purpose of restructuring the national narrative is a long and painstaking one. Thus, a lengthy period passed between Byzantine history being accepted as part of the national narrative, and it actually being used in the fields of national symbolism and representation. For instance, it was only at the end of the nineteenth century that Byzantium was included in schoolbooks; the Byzantine and Christian Museum of Athens was established in 1914, the Association for Byzantine Studies in 1918, while two professors of Byzantine art and history were first appointed at the University of Athens in 1912 and 1924 respectively. ${ }^{17}$ In a similar manner, the first piece of legislation for the protection of Byzantine churches and fortresses was enacted in 1921, and the Archive of the Byzantine Monuments in Greece was founded in $1935 .{ }^{18}$ What is particularly interesting in the process unfolding in the latter part of the nineteenth century and the first part of the twentieth, is that interest in Byzantium was supported by interest in folklore, which linked the Byzantine past to 
modern times. The study of folklore (laographia) was understood as providing access to the reality of the Byzantine past. ${ }^{19}$

Within this framework, the affluent and intellectual elite of the country undertook the role of the gatekeepers of Byzantine culture. They called on Byzantium as the part of their national past that would bring them closer to the authentic Greek soul, and, at the same time, educate 'ordinary' people or 'peasants' about their national role; as bearers of folklore, they were equally seen as unwitting bearers of authenticity. There was a growing romantic feeling towards this national medieval past. Ion Dragoumis, for instance, a diplomat, politician and writer, who organised the Greek communities in Northern Greece during the irredentist Macedonian struggle and was very influential in the development of the ideological framework of the early twentieth century, wrote in 1927:

I enjoy that I, a Modern Greek man, can visit Byzantine cities, walk in their old streets, and enter their old houses... They are the places of Greeks, their houses, their streets; they are all Byzantine and lordly. It seems strange to me that I, a Modern Greek man, can actually be related to Byzantine Greeks. ${ }^{20}$

A blend of nostalgia, continuity and responsibility towards connecting the past with modernity is evident in this passage. In another work, Dragoumis connects Byzantium to the irredentist ideals of the Great Idea, where he claims that it was the 'fixation' of Europeans and the Greeks who were influenced by them that had 'shaped the idea of a "small Greece"". He asserted, however, that "the people had always in them, like a constant national desire, the Byzantine tradition of the empire', which in his view held a parallel with Greek folk tradition and demotiki (i.e. the language of the people). ${ }^{21}$

The same intellectuals displayed antagonism towards other Balkan countries that expressed an interest in Byzantium and claimed part of its inheritance; this movement not only included historiographers, but also members of the ruling classes, for instance, Princess Maria of Romania (1875-1938). ${ }^{22}$ Greek intellectuals believed that Greece was in a privileged position as far as its claims to Byzantine heritage were concerned, as it was where most surviving Byzantine monuments could be found; therefore, Greece had to be the topos par excellence for the collection and study of the Byzantine past. ${ }^{23}$ Collecting these monuments and making them part of private and public narratives about the past, was therefore considered a responsibility of Greek intellectuals of means to explore, define, re-define and protect the national 'self'.

\section{Byzantium and the Arts and Crafts movement: from Britain to Greece}

The medieval past and its artistic and material legacy, as well as its relation to the 'art of the people', held a prominent position in the Arts and Crafts movement that developed in Britain towards the end of the nineteenth century. John Ruskin (1819-1900) and William Morris (1834-1896), who spearheaded the movement, urged for a turn towards art they considered untainted by mass production and rising factory culture, as a bearer of imagined purity and morality that was in danger of disappearance. They promoted the revival of Gothic art to counteract the commercialisation and industrialisation of contemporary art, which they thought of as inadequate and based on immoral values. Morris, in particular, went even further to support Byzantine art as 'new-born Gothic', ${ }^{24}$ 
and that 'nothing more beautiful than [Byzantium's] best works has ever been produced by man'. ${ }^{25}$ Byzantium, therefore, was identified as the period that would allow both for an escape from classical and neoclassical artistic values, as well as for the promotion of a new understanding of the arts. This new understanding placed emphasis on people and traditions that had previously been ignored, and acknowledged a continuation of distant traditions that could also determine the development of modern contemporary life. ${ }^{26}$ Byzantine art was as much 'Eastern Gothic' as it was 'new-born modern'. ${ }^{27}$ Byzantium thus became the focal point for two, quite contradictory ideas: it appealed to the nostalgic and the nationalistic as a source of authenticity, while at the same time, it was fast becoming a representation of modernity, in the sense of creating a new, contemporary understanding of the self and the world. ${ }^{28}$ As a result, Byzantine art and architecture was subject to a re-appraisal, which coincided with the establishment of historical studies and the introduction of Byzantium to the historiography of Greece and other countries, ${ }^{29}$ as discussed in the previous section.

This link between the artistic values of the Arts and Crafts movement and the collection and study of the medieval Greek past was facilitated through the British School at Athens (BSA), established in $1886 .{ }^{30}$ As Kakissis wrote:

Interest in Byzantium at the turn of the century was at a peak. Byzantine art and architecture very much melded with the philosophies of the Arts and Crafts Movement and many scholars saw Byzantium as the closest remnant of the continuity between Classical and Modern Greece. These intellectuals moved in the same circles and as a result numerous institutions like the British Museum, the British Academy, the Society of Antiquaries, the Society of the Dilettanti, the Society for the Promotion of Hellenic Studies, the Royal Institute of British Architects (RIBA), the Royal Academy and various Universities including Oxford, Cambridge and the University of London all had members involved in the study of Byzantium. These institutions were the very ones that rallied behind the founding of a base in Greece for British scholars. ${ }^{31}$

And this is what the BSA indeed became: a base where intellectuals of different backgrounds and interests - including the Byzantine past, folklore and language - could come together and exchange views and perceptions. ${ }^{32}$

A huge influence in promoting Byzantium and its connection to the Arts and Crafts movement was R.M. Dawkins, director of the British School at Athens between 1906 and 1914, and first professor of Byzantine and Modern Greek Studies at the University of Oxford. ${ }^{33}$ Dawkins was strongly influenced by William Morris and played a significant role in promoting the study of Byzantine art and architecture, as well as the study of folk tales and dialects in Greece. ${ }^{34}$ It was during his time as director of the BSA that the Byzantine Research and Publication Fund was established. ${ }^{35}$ Dawkins was also interested in folk art: between 1902 and 1914, he collected embroideries, first through dealers and then via field trips that he undertook with his successor in the directorship of the BSA, the influential, well-connected and keen collector of embroideries, A.J.B. Wace. ${ }^{36}$ Dawkins wrote in his unpublished autobiography:

With Wace I had two notable island journeys. In 1906 we visited the Dodecanese, and in 1907 the Cyclades; we were mainly in search of 
embroideries but did a lot of dialect collecting. ... at Anaphi ... we bought so many embroideries that we ran out of money and had to go back to Athens to load up again... ${ }^{37}$

Collecting contemporary ethnographic material such as embroideries, along with archaeological objects, was a common practice for both these British intellectuals and their Greek counterparts. This practice reflected their academic and scholarly pursuits, artistic beliefs and interests, as well as their ideological and political views.

\section{Byzantine salons}

The period between the two world wars saw a number of private collections of Byzantine, or pseudo-Byzantine, monuments assembled in Athens, mostly in private homes, as documented by Alexandros Philadelpheus (1866-1955), a prominent archaeologist of the time, and his contemporary, Angeliki Hatzimichali (1895-1965), an influential folklorist and author. Hatzimichali authored the entry titled 'Folk Life' in the tenth volume of the Great Hellenic Encyclopaedia, published in 1934. She concludes the entry with 'Exhibitions/Stores', a section in which she lists a number of men and women whose homes are adorned with 'excellent wood carved works of post-Byzantine and folk art'. She argues that these works, which come from 'older houses' across Greece, offer a sample of the 'character' of traditional Greek architecture and in their new settings are 'organically combined with contemporary architecture and home making'. ${ }^{38}$

One year later, in 1935, Alexandros Philadelpheus published a small guidebook on Athenian museums, which included a section on the city's 'salons and Byzantine collections'.

Lately in Athens, many lovers of art, gentlemen and ladies of the upper class manifest a decided inclination for the byzantine objects, stuffs, knick knacks, icones (sic), furniture, etc. So there are now many Saloons (sic) which are constructed and decorated in the Byzantine style and which diserve (sic) a visite (sic). In these saloons (sic) the precious embroideries and oriental carpets are particularly to be admired. ${ }^{39}$

Encouraging his readers, likely non-Greeks, since the book was written in English, to visit these private spaces, Philadelpheus testifies to the dual role of these rooms: homes that also serve as museum spaces; private rooms that can also be visited as public displays. ${ }^{40}$ Philadelpheus focuses on the more prominent Byzantine salons of the era: all but one (the salon of the writer Alexandros Pallis (1851-1935), belonged to bourgeois women, who had assembled these Byzantine rooms in their family homes. The most famous, according to Philadelpheus, was the salon created by Eleni Kanellopoulou-Zouzoula (1870-1936), the wife of a conservative politician, and member of the Lyceum Club of Greek Women, which was created in 1911 by the most prominent Greek suffragette, Callirhoe Parren. ${ }^{41}$ Kanellopoulou-Zouzoula had assembled her salon (featuring woodcarvings and artefacts) in her family home at 11, Kaplanon Street in central Athens. Authentic woodcarvings from a Byzantine church in Melenico, a village in East Macedonia, today South Bulgaria, formed the backdrop of her parlour, while Byzantine and Byzantine-style furniture, carpets and decorative objects, such as a fourteenth century clay plate, dominated the 
interior. The space was designed by the architect Aggelos Koryzis, the woodcarver Georgios Vlachos and the painters Dimitris Pelekasis and Yiannis Tsarouchis. The architect Aristotelis Zachos (1871-1939) was also involved in the setting of this space. ${ }^{42}$ Zachos was an important representative of the 'return to the roots' movement which supported the historical paradigm of continuity as well as the search for authenticity in folk culture, which he, along with his contemporaries, believed was a direct continuation of the Byzantine cultural tradition. ${ }^{43}$

The only known surviving photograph [Figure 1], together with Philadelpheus' description, suggest that the room resembled those created by Eleni Stathatos (18871982), which are better documented. Stathatos was probably the most well-known Greek female collector of this era and is mentioned by both Philadelpheus and Hatzimichali. She had a large collection of works of art dating from antiquity to the eighteenth century. The reason she is so well-known is that, unlike Kanellopoulou-Zouzoula and other female collectors whose collections were dispersed after their death, Stathatos donated her collection, while still living, to three Athenian institutions: the National Archaeological Museum of Athens (in 1957), the Benaki Museum (in 1964) and the American School of Classical Studies (in 1969). Prior to donating her collection, the objects therein had been displayed at her family mansion at 22, Herodotou Street. Three ground-floor rooms of different dimensions had been reserved for the display of the collection [Figure 2]. The first room was assembled sometime around 1920; she called it her 'small living room'. The focus of this room was the fireplace, which comprised bright blue antique ceramic tiles that she had purchased in Paris during her honeymoon, in the belief that they had been sourced from Rhodes. The rest of the room featured woodcarvings from old churches around Arta in the region of Epirus (northwest Greece). Next was the 'large living room', or the 'salon from Kozani'. The wood-carved panels of this room had been acquired in 1928. They had been sourced from a townhouse built in 1732 in a town in northern Greece. ${ }^{44}$ Stathatos purchased the woodcarvings and brought them to Athens; adorning the main living room, they became the focal point of her collection. Stathatos designed and supervised the fitting of the woodcarvings herself; in order to fit the woodcarvings into the dimensions of the Athenian space, she decided to have the windows of the room permanently covered. ${ }^{45}$ She lived with her family in this room under artificial lighting more or less until the end of her life. Her devotion and love for this particular room has been well documented:

Ah, I loved that room so much... when they took out the last piece of the woodcarvings of the large living room [to take them to the Benaki Museum] the house became alien to me. I had lived with it for thirty years. I had spent much time in thought within it.... ${ }^{46}$

Stathatos' woodcarvings were not in fact Byzantine, dated as they were from the late eighteenth century. ${ }^{47}$ They were nevertheless used to recreate a 'Byzantine' space; she even went as far as to have the woodcarvings painted in a darker colour (as she imagined the Byzantine style to be). According to her granddaughter, Stathatos styled herself as 'a Byzantine princess', wearing long blue dresses and earning the nickname: 'the Byzantine lady'. ${ }^{48}$ This concept of a 'Byzantine princess', or a 'Madonna' surrounded by her personal collection of precious decorations is a common theme in novels of the period, 
which often included descriptions of Byzantine rooms and the women who put them together (see next section).

Both Kanellopoulou-Zouzoula and Stathatos used their Byzantine rooms as reception spaces; for Zouzoula, who was also the first children's book author in Greece, her salon was a place where she received her literary acquaintances to discuss literature and the arts. For Stathatos, her parlour was where she received archaeologists and architects that shared her interest in antiquities and the past, among them international archaeologists and antiquarians, as well as members of the British School in Athens and the American School of Classical Studies. ${ }^{49}$ In the case of Kanellopoulou-Zouzoula, who did not bequeath her salon to an institution, no information is available about what actually happened to her collection of artefacts following her death in 1936.

Information is also scarce around other salons mentioned by Philadelpheus and Hatzimichali, such as those by Sophia Deligeorghis (1885-1939), Andromache Mela (née Schliemann) (1871-1962), and Eugenia Ambott (founding member of the Society for Byzantine Studies, in 1918).

Meanwhile, we are also aware of other notable salons in this period, often not as well documented, but mentioned in passing in written accounts. The room that was donated to the Benaki Museum by the heirs of Alexandra Benaki-Choremi, sister of Antonis Benakis, the founder of the museum bearing his name, was 'rescued by her in the 1930s' ${ }^{50}$ It was also probably used as a 'Byzantine salon' in her own house, although no information of this use is currently available [Figure 3]. The Benaki Museum displays this room to this day alongside the one donated by Stathatos; the salon has been meticulously reconstructed, but no information is provided regarding its role as interior decoration or its setting as a collection of decorative and religious objects.

Similarly, Prokopiou discusses the history of the woodcarvings of the house of G. Voulgaris in Hydra, another interior currently on display at the Benaki Museum, that were bought by the institution in $1974 .{ }^{51}$ Prokopiou argues that sometime after 1912 (when the original house was demolished) the woodcarvings were purchased by Maria VoulgariKarapanou, who had them installed in her house at Rigilis street in Athens. They stayed there until the Second World War. Maria was the wife of Alexandros Karapanos (18731946), diplomat and politician, and daughter of Lazaros Voulgaris (Member of Parliament). She was therefore also a member of the intellectual elite and the interior that we currently see in the museum is likely to have been part of her 'Byzantine salon'.

When the salons originally put together by Stathatos, Choremi and Karapanou were transferred to the Benaki Museum, a new life started for them. Following objective historical standards, they were restored, studied and displayed as period rooms and recreations of typical domestic settings; the focal point moved away from their being a reflection of the taste of their collectors. As the museum catalogue explained regarding the room donated by Stathatos: 'for museological reasons...the present restoration renders the organisation of space during the $18^{\text {th }}$ century', despite the fact that 'the room was originally [meaning when it was first introduced into the museum in the 1960s] restored as it had been reconstituted inside the donor's house'. ${ }^{52}$ In other words, despite the fact that the room had been assembled in the form the collector had envisioned it when it was first transferred to the Benaki Museum in the 1960s, it was subsequently restored 
to its eighteenth century form in the course of the museum's refurbishment in the $2000 \mathrm{~s}$. All three reception rooms today host artefacts donated to the museum by other collectors as well as the ones that had put the rooms together in the first place; they serve as museum period rooms, i.e. full-scale environments of the eighteenth century to which the woodcarvings originally belonged. Their previous lives as domestic collections/exhibition spaces and their role in the development of Greek museography and understanding of the past are therefore silenced and remain largely unknown.

The reinterpretation of these interiors in a more academic manner in the museum suggests that they were seen as subjective expressions of eclectic female taste, and not 'scientific'; however, this was not the paradigm followed when similar artistic interiors were created by 'serious' male collectors. The example of Dionysios Loverdos (18781934), who is mentioned by Hatzimichali ${ }^{53}$ as one of the owners of these decorated spaces, demonstrate this. His house remains the most well-known example of neoByzantine taste in the period under examination. He was the founder of the Laiki Bank (Popular Bank), and probably the richest Greek citizen of his time. ${ }^{54}$ In 1922, he purchased his first collection of post-Byzantine icons assembled towards the end of the nineteenth century by the distinguished philologist and journalist Alexios Kolyvas (father of Angeliki Hatzimichali). Two hundred icons from this collection had been exhibited in 1912 at the $16^{\text {th }}$ International Conference of Orientalists, which was held in Athens that year. ${ }^{55}$ In 1923, Loverdos purchased architect Ernest Ziller's family home to both live in and to house his collection, ${ }^{56}$ and redesigned the interior with the help of Aristotelis Zachos. Zachos crafted eighteen different reconstructions of ecclesiastic and popular architecture and decoration across the ground and first floors: among them, a reconstruction of three Byzantine churches, as well the interior of a traditional house on the island of Skyros. ${ }^{57}$ Polychronis Renieris, another architect and 'museum expert', finished the work Zachos had started and prepared the works for display, along with the artist Dimitris Pelekassis. ${ }^{58}$

Loverdos inaugurated his house museum in 1930, during a major international conference on Byzantine studies; the museum operated as such, despite the fact that it shared a space with the family home, long after his death in 1934. The exhibition catalogue was published by Loverdos' widow, Artemis, in 1946. In 1979, the collection was donated to the Byzantine and Christian Museum in Athens and a few years later the building itself was also donated to the museum by his daughter. Efforts are currently in progress to reconstruct the building and exhibit the collection in its original setting, as a branch of the Byzantine Museum. ${ }^{59}$

Loverdos differentiated himself from other collectors from the beginning. By turning his house into a museum, he institutionalised his collection, his aesthetics and his home, taking them to the level of serious, academic effort, exactly like Antonis Benakis, who had also opened his private museum in the same year (1930). In that sense, his house became a domestic museum, following the trend described by Anne Higonnet, ${ }^{60}$ in which many domestic collections of art assembled between 1890 and 1940 around the world turned into collection museums, i.e. institutions aiming to display not just art objects, but also an individual vision of how art should be experienced. The most significant collection museums were reflective of their era, portraying a sensitive balance between 
transitioning ideals: on the one hand, they were institutions, and on the other, they declared the subjectivity and individualism of the collectors themselves. Kostis Kourelis offers another example of the 'fashion for domestic museums (...) in the 1930s', also in Greece, this one was the brain-child of Rhys Carpenter, Director of the American School of Classical Studies in Athens, who chose a domestic structure to reconstruct and house a 'Byzantine Museum' in Corinth, in the 1930s. ${ }^{61}$ This project was ultimately abandoned and largely forgotten.

\section{National and gendered perspectives}

In the novel 'The Veil of Isis', published in 1926, Aggelos Tanagras, novelist, doctor and founder of the Hellenic Society of Psychic Research (1923) described the relationship between his protagonist, Tellos Argillis (a persona that he admitted to being autobiographical) and Athinais, a beautiful and charming, albeit superficial and capricious lady. ${ }^{62}$ Their first private meeting takes place in the 'small, doll-like salon of purely Byzantine style loaded with church woodcarvings, embroideries and icons, where only a discreetly-lit Madonna would fit in'. ${ }^{63}$ The image of the Madonna-like lady charms the young Tellos, who claims that '[Y]ou are not the lady I've met [on other social occasions]... but a lady of the court of Byzantine times... ${ }^{64}$ This small salon is also the setting for one of the closing scenes of the novel, where the relationship ends with the death of the female protagonist. As inspiring and alluring as she had been for the young author, she is ultimately proven to be dangerous for his mental and emotional wellbeing.

This allegorical novel - marketed under 'women's psychology' and as a 'feminist novel' - reveals an archetype based on female owners of Byzantine salons and provides an interesting backdrop for the discussion of these salons. For their owners and collectors, these rooms functioned as alter egos, an opportunity to project an image of themselves as idealised versions of Byzantine personalities, combining the mystery of the era with the modernity inherent in the contemporary use of such spaces. Much like the novel's heroine - Athinais - Stathatos, as well as Kanellopoulou-Zouzoula, Choremi and Loverdos, portrayed themselves through these rooms as intellectual patriots who recognised the importance of the missing link connecting ancient Greece with the modern one, i.e. the Byzantine period. By presenting themselves and their households as parts of the Byzantine past, they played out their chosen national narrative: in collecting the artefacts and thus salvaging them for the sake of the nation, they also provided edification for their visitors. It is no coincidence that in most of the known collections, the Byzantine woodcarvings and the artefacts come from northern Greece (Epirus, Macedonia, Thrace), considered by Zachos the 'cradle of Greekness', or eastern Greece (Rhodes), i.e. regions of the country that had just been added to the Hellenic territory, or that remained just outside of it. ${ }^{65}$

The domestic character of those assemblages is what allowed for the participation of women. The historical feeling evoked as the women received guests in these spaces, full of domestic, family and religious decorations and souvenirs of the past supported an intensely romantic mood. The past, 'our past', was becoming both present and distant: they could see themselves coalescing with history. ${ }^{66}$ The domestic objects that made up 
the historical interior linked the owner to the national past through the family and the home, validated the importance of the study of the ordinary and quotidian and constructed a romantic vision of authentic folk tradition. ${ }^{67}$ The idea of authenticity was critical in the late nineteenth century and formed a key notion in the idea of the museum/collection as understood by Ruskin or Morris. In their view, 'old things' were endowed with a newly understood idea of authenticity and had the potential to reshape the future. ${ }^{68}$ Ruskinian museums had as their primary concern the salvaging or preservation of these traces of the past. Through its artistic quality, this past enshrined a superior nature, valorised crafts and craftspeople and saw artefacts as vehicles for nostalgia and romantic longing. A mixture of progressiveness and nostalgia underpinned the impulses to salvage and rescue. ${ }^{69}$ These are exactly the ideas that we find in these Byzantine salons.

Women were considered the creators and sustainers of family histories; by contributing to such collections, they took on the role of keepers of national history, as a form of family history; the nation becomes the family, and the role of women is to keep this family (the nation) intact. This is also related to the construction of the self and the other: the self, in this case the national self, is constructed through the domestic, the familial, the local, the souvenir and the relic, all of which are authentic and can bring together history and geography through identity. This type of history and geography (identity-related) could be constructed in an alternative way, since Byzantium was not limited by the scholarship and knowledge-based understanding of the classical past, itself an arena of men. Byzantium gave women an opportunity to engage in debate about important objects and gave prominence to values such as empathy, aesthetic qualities, sensibility, memory, affect, subjectivity and relationality, in contrast to the traditionally masculine pursuits of academic objectivity and systematicity. The artefacts in these collections were not valued as specimens or examples of academic pursuits, but for their power to initiate emotions and attachments to both national ideas and the idea of home. Icons, tapestries, carpets, vases and other decorative objects were appreciated because they created ensembles that were emotional, personal, subjective, as well as expressions of the nation's continuity, of the national self. The value of such an understanding was facilitated by the introduction of Byzantium in the national narrative, i.e. a period that was more recent, not yet fully appropriated by male academics, and closely connected to religion, another female/family domain. It combined the values of Romanticism and those of the women's suffrage movement, as this was experienced in Greece and expressed through the work of Callirhoe Parren. She had founded in 1911 the Lyceum Club of Greek Women and had put forward a proposal regarding women's civil and social rights, focusing on education and professional opportunities for Greek women, Her version of 'feminine citizenship' aimed to redefine traditional gender roles, however within the framework of nationalist ideology. ${ }^{70}$ This connection ultimately tainted the interest in Byzantium and the creation of Byzantine parlours with suspicions of frivolity and danger, as we saw in the depiction of Athinais.

While they appeared to conform to accepted models of domestic femininity, the women used their collections to negotiate a presence for themselves in the public sphere of culture. Hovering between home and museum, domestic and public display, these collections lent themselves to alternate gender possibilities. ${ }^{71}$ Stathatos, for example, 
claimed the status of a real collector and used her collection as a means of public appearance in the major cultural institutions of Athens. ${ }^{72}$ She offered her acquisitions for study to important academics and researchers of her time (such as A.J.B. Wace), and facilitated and financed the publication of scholarly catalogues of her collection. ${ }^{73}$ When a part of it was donated to the National Archaeological Museum in Athens, the displays followed traditional archaeological taxonomies and presentation methods. ${ }^{74}$ The reinterpretation of her collection in the institutions she donated them is also related, at least in part, to gender and is an example of the ambivalent relationship between the home and the museum. As mentioned previously, her domestic approach was accepted at first when the salon entered the Benaki Museum, but was eventually rejected, and replaced by the academic, neutral, or male gaze. The language of creativity as well as the expression of subjectivity was lost when the collection was re-interpreted in the museum. Other salons had similar experiences in being housed by institutions, for example the salons by Alexandra Choremi and Maria Voulgari-Karapanou.

Things are slightly different in the case of Dionysios Loverdos. He made a more active claim to his individual appropriation of the past, established his own domestic space as a museum and used all the resources available to him to position himself as a legitimate connoisseur. He took a decisive role in the mission set out by the intellectual elite of his country - promoting the culture of Hellenism. The phrase adorning the entrance to the Loverdos Museum, as noted by the 1946 edition of the museum catalogue, is explicit:

[The museum assembles icons and other Byzantine artefacts] to provide a reminder of the fact that the Greeks owe to this sacred art of their fathers the preservation of their faith and national unity, the solidification (strengthening) of their souls during the great struggles of the nation, and even their own freedom. ${ }^{75}$

As was tradition at the time, Loverdos often had himself photographed with important museum visitors [Figure 4], while the choice to open his collection museum during a major international academic conference is also an indication of his efforts to include his work in the public's understanding of both Byzantium and Byzantine art.

Stereotypes and gendering of art appreciation were thus reinforced: men created artistically inspiring environments, while women created personal sanctuaries inspired by sentimentality, only occasionally opened to visitors, that were either to be forgotten once the person passed away, or become 'academic' by being accepted in a museum. Aggelos Tanagras' 'feminist novel', as well as the stories of collections/private museums such as those by Eleni Kanellopoulou-Zouzoula and Eleni Stathatos support this view.

\section{Conclusion}

Kate Hill, ${ }^{76}$ in her discussion of women and museums in Britain from 1850 to 1914 , argues that the interrelation between the ideas of home and domesticity, the private and the public, as well as gender, are much more nuanced and complicated than often thought. The classic binary of masculine vs. feminine and public vs. private, became much more contested and blurred towards the end of the nineteenth century. While women retained 
their control over the domestic sphere, they tended to bring this domestic aspect into the public eye, as a means of strengthening their voice, ${ }^{77}$ but also to reflect their feminine roles. The relationship between the domestic space and the museum also reflects this ambiguity: museum collections adapted to include mundane, ordinary, and home-related artefacts or artefacts valued for private (personal or family) reasons, while museum displays acquired a much more 'domestic' character, often in the form of period rooms. ${ }^{78}$

In this paper, I argued that Byzantine interiors recreated in Greek domestic spaces at the beginning of the twentieth century hold an interesting double role as both public and private spaces, designed to express and support patriotism and a new understanding of national history, as well as awareness and internalisation of the international movement of modernism. This awareness was enriched and supported by Western intellectuals, who influenced and participated in Greek social circles, as for instance, members of the British School at Athens. ${ }^{79}$ In this way, the well-educated, bourgeois society of Athens, once influenced by international trends, internalised and re-worked those trends towards an ideology that largely shaped modern Greece.

'Byzantine salons' were material expressions of a specific way of thinking that brought together the past and the future of the country. The collectors, both male and female, aimed to accomplish important tasks: to connect history with their own individuality and to combine their private interests with a historical period they considered important for the identity of the nation. They aimed to blur the boundaries between private and public, by opening their private, domestic collections into the public domain, either by making them the centre of their social life, inviting outsiders to visit and explore them - as in the case in the guidebook written by Philadelpheus - or, in the case of male collectors, by institutionalizing them and thus making them central in terms of the intellectual life of the city and the country. Finally, these collections aimed to define and assert artistic taste, by showcasing artefacts which were important, highly appreciated and valued. It is through such spaces and collections that Greek intellectuals attempted to invent their own authentic modernism and appropriate Byzantium for their nationalistic project. In the words of Kostis Kourelis, '[B]y emulating living traditions resident in Byzantine and vernacular models, Greece could invent its own authentic modernism, ${ }^{80}$ often without realising how widespread the interest for this period and its art was. Ultimately, these spaces, these collections, these private 'museums', whether official or not, deserve to be better studied and understood and find their place in the history of Greek museums, as well as in the history of museology and museums in general.

\section{Acknowledgements}

I would like to express my gratitude to the anonymous reviewers and the editor of the journal for their comments on a previous version of this paper. My thanks are due to Xenia Politou and Sophia Handaka from the Benaki Museum for all their support during the research for this paper. My friend and colleague Andromache Gazi gave me feedback on a previous version and I am grateful to her for this but also for her encouragement and support. Of course, I am solely responsible for any remaining errors or omissions. 
${ }^{1}$ M. Greensted, 'The Arts and Crafts Movement: exchanges between Greece and Britain (18761930),' (M.Phil. diss., University of Birmingham, 2010); D. Kotoula, 'Arts and Crafts and the Byzantine: the Greek connection,' in Byzantium/Modernism, ed. by R. Betancour and M. Taroutna (Leiden: Brill, 2015), pp. 75-101.

${ }^{2}$ I. Nilsson and P. Stephenson, 'Introduction,' in Wanted: Byzantium. The Desire for a Lost Empire, ed. by Ingela Nilsson and Paul Stephenson (Uppsala: Uppsala Universitet, 2014), p. 2. For recent contributions, see P. Stephenson, ed., The Byzantine World (London and New York: Routledge, 2010); M. Altripp, ed., Byzanz in Europa: Europas östliches Erbe (Turnhour: Brepols, 2011); F. Kolovou, ed., Byzanzrezeption in Europa: Spurensuche über das Mittelalter und die Renaissance bis in die Gegenwart (Berlin: De Gruyter, 2012); O. Delouis, A. Couderc and P. Guran, eds., Héritages de Byzance en Europe du Sud-Est à l'époque modern et contemporaine (Athens: École française d'Athènes, 2013).

${ }^{3}$ Nilsson and Stephenson, 'Introduction', pp. 1-2.

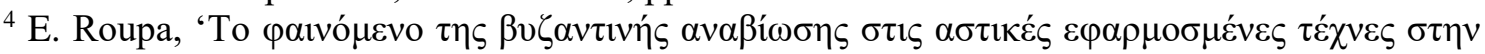

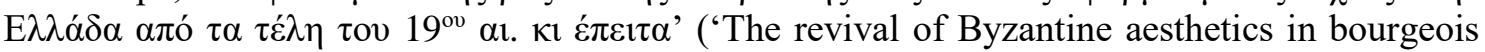
applied arts and design in Greece, since the turn of the $20^{\text {th }}$ century') (paper presented at the First Scientific Symposium of Neo-Hellenic Ecclesiastic Art, Athens, Greece, 2009), pp. 617-638.

${ }^{5}$ See A. Vezenkov and T. Marinov, 'The concept of national revival in Balkan historiographies,' in Entangled Histories of the Balkans, vol. 3: Shared Pasts, Disputed Legacies, ed. by R. Daskalov and A. Vezenkov (Leiden: Brill, 2015), pp. 406-462.

${ }^{6}$ For a discussion on Byzantium and its historiographical perception in Greece and the Balkans, see D. Mishkova, 'The afterlife of a commonwealth: narratives of Byzantium in the national historiographies of Greece, Bulgaria, Serbia and Romania,' in Entangled Histories, ed. by Daskalov and Vezenkov (Leiden: Brill 2015), pp. 118-273. Also, S. Chondrogiannis, Byzantium in the World. Artistic, Cultural and Ideological Legacy from the $19^{\text {th }}$ to the $21^{\text {st }}$ century (Thessaloniki: Centre for Byzantine Research, 2017).

${ }^{7}$ See, for instance, the views of Adamantios Korais, in Mishkova, p. 131.

${ }^{8}$ A. Liakos, 'Hellenism and the making of modern Greece,' in Hellenisms. Culture, Identity and Ethnicity from Antiquity to Modernity, ed. by K. Zacharia (Farnham: Ashgate, 2009), pp. 201236.

${ }^{9}$ Ibid, p. 208.

${ }^{10}$ Mishkova, p. 148.

${ }^{11}$ Mishkova, p. 149.

${ }^{12}$ Spyridon Zambelios was born in Lefkada; he studied Law in Corfu, Italy and Germany. Through his involvement in politics in the 1850s, he developed an interest in historiography. Konstantinos Paparrigopoulos was born in Constantinople; his family fled Ottoman lands for Odessa following his father's murder at the start of the Greek revolution in 1821. They lived there until 1930. When they came to Greece, Paparrigopoulos worked for the Ministry of Justice, until he was made redundant since he did not have Greek citizenship. In 1851, he was appointed a professor of History at the University of Athens, a position he held until his death.

13 Mishkova, p. 152. Also, D. Christodoulou, 'Making Byzantium a Greek presence: Paparrigopoulos and Koumanoudes review the latest history books,' in Héritages de Byzance, ed. by Delouis et al. (Athens: École française d'Athènes, 2013), p. 245.

${ }^{14}$ Liakos, p. 208.

${ }^{15}$ For a very sound and detailed argument, see D. Stamatopoulos, 'The Western Byzantium of Konstantinos Paparrigopoulos,' in Imagining Byzantium: Perceptions, Patterns, Problems, ed. by Alena Alshanskaya, Andreas Gietzen, and Christina Hadjiafxenti (Mainz: Verlag des RömischesGermanischen Zentralmuseums, 2018), pp. 39-46. Also, Mishkova, p. 161.

${ }^{16}$ Liakos, p. 209.

${ }^{17}$ Liakos, p. 210; Chondrogiannis, pp. 39-91; also, T. Kioussopoulou, 'Byzantine studies in Greece (1850-1940),' in From the Christian Collection to the Byzantine Museum (1884-1930), 
ed. by Olga Gratziou and Anastasia Lazaridou. (Athens: Christian and Byzantine Museum, 2006), pp. 25-36.

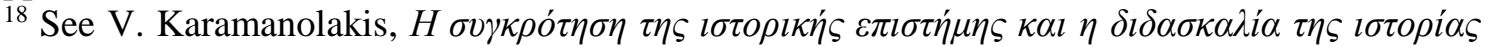

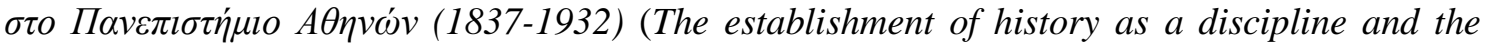
teaching of history at the University of Athens (1837-1932)) (Athens: Historical Archive of Hellenic Youth, 2006), pp. 320-324.

${ }^{19}$ See R. D. Argyropoulos, Les intellectuels grecs a la recherche de Byzance (1860-1912) (Athens: Institut de Recherches Néohelléniques, 2001); E. Gazi, Scientific National History: The Greek Case in Comparative Perspective (1850-1920) (Frankfurt am Main: Peter Lang, 2015).

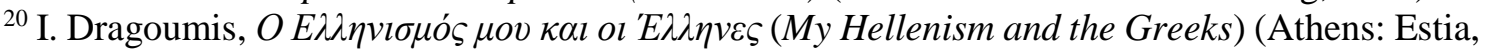
1927), p. 21. All translations are by the author unless otherwise stated.

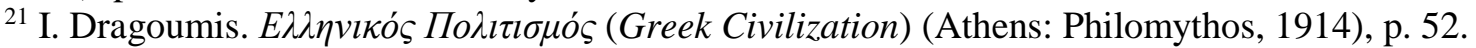

${ }^{22}$ For Princess Maria, see Roupa, p. 329. For competing national historiographies, see Vezenkov and Marinov, 'The concept of national revival'.

${ }^{23}$ Roupa.

${ }^{24}$ William Morris, The Collected Works, Vol. XXII (New York: Russel \& Russel, 1966), p. 185.

${ }^{25}$ William Morris, Gothic Architecture, a lecture for the Arts and Crafts Exhibition Society (Hammersmith: Kelmscott Press, 1893), p. 13.

${ }^{26}$ Kotoula.

${ }^{27}$ Morris, The Collected Works, pp. 187, 275, 279; Morris considered Byzantium a turning point in the development of decorative arts, which started a revolution in architecture and design and allowed for a connection between the East and West. For a discussion, see T. McAlindon, 'The idea of Byzantium in William Morris and W.B. Yeats,' Modern Philology 64(4) (May 1967), pp. 314-7.

${ }^{28}$ E. Outka, Consuming Traditions: modernity, modernism and the commodified authentic (Oxford: Oxford University Press, 2008), pp. 5-7.

${ }^{29}$ Kotoula, p. 81.

${ }^{30}$ D. W. J. Gill, Sifting the Soil of Greece: The early years of the British School at Athens (18861919) (London: Institute of Classical Studies, 2011).

${ }^{31}$ A. Kakissis, 'The Byzantine Research Fund Archive: encounters of Arts and Crafts architects in Byzantium,' in Scholars, Travels, Archives: Greek History and Culture through the British School at Athens, vol. 17 of British School at Athens Studies Series (Athens: British School of Athens, 2009), p. 130.

${ }^{32}$ See Kotoula, p. 84.

${ }^{33}$ More information about Dawkins' biography can be found in: P. Mackridge, 'From archaeology to dialectology and folklore: the role of the British School at Athens in the career of R.M. Dawkins,' in Scholars, Travels, Archives: Greek History and Culture through the British School at Athens, vol. 17 of British School at Athens Studies Series (Athens: British School of Athens, 2009), pp. 49-58.

${ }^{34}$ Kotoula, p. 84. Also, P. Mackridge, 'R.M. Dawkins and Byzantium,' in Through the Looking Glass: Byzantium through British Eyes, ed. by R. Cormack and E. Jeffreys (Aldershot: Ashgate, 2000), pp. 185-195.

${ }^{35}$ Kakissis.

${ }^{36}$ A.J.B. Wace became the director of the BSA in 1914; his duties were suspended during WWI, and he resumed his role between 1920 and 1923. His collection of embroideries is now in the Victoria and Albert Museum in London. See D. Gill, 'Wace, Alan John Bayard (1879-1957), archaeologist,' in Oxford Dictionary of National Biography, ed. by D. Cannadine (Oxford: Oxford University Press, [2004]). Also, A. French, 'The Greek embroidery collecting of R.M. Dawkins and A.J.B. Wace,' in Scholars, Travels, Archives: Greek History and Culture through the British School at Athens, vol. 17 of British School at Athens Studies Series (Athens: British School of Athens, 2009), pp. 77-90.

${ }^{37}$ Quoted in French, p. 79.

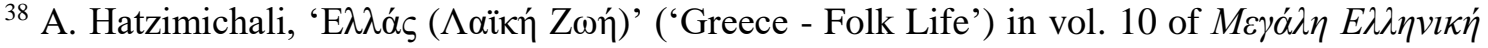

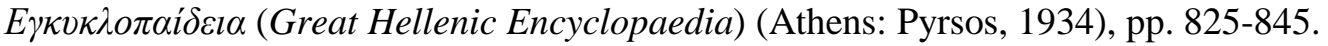

${ }^{39}$ A. Philadelpheus, The Museums of Athens (Athens: Cavounidis, 1935). 
${ }^{40}$ Cf. K. Hill, Women and Museums, 1850-1914: Modernity and the Gendering of Knowledge, (Manchester: Manchester University Press, 2016), p. 7ff. This 'invitation' was addressed to people of similar status and means, and not to 'ordinary tourists'.

${ }^{41}$ On the Lyceum of Greek Women, its founder and the exhibitions of folk art organised by its members, see A. Bounia, 'Exhibiting women's handicrafts. The arts and crafts exhibitions of women's organizations in Greece at the dawn of the 20th century,' Gender and History 26(2), (August 2014), pp. 287-312.

${ }^{42}$ Zachos is also mentioned by Hatzimichali, p. 844, as the owner of a Byzantine salon. See also, Roupa, pp. 333-4, note 80, and K. Kourelis, 'Byzantium and the Avant-Garde: Excavations at Corinth, 1920s-1930s,' Hesperia 76 (2007), 406. The house of Eleni Zouzoula hosted an art exhibition in 2017, which presented an opportunity for the public to get to know her story. See N.

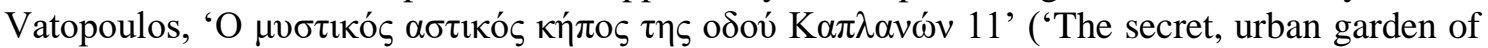
11, Kaplanon Street'), Kathimerini, 8 January 2018, <https://www.kathimerini.gr/941824/article/politismos/polh/o-mystikos-astikos-khpos-thsodoy-kaplanwn-11> [accessed 02 December 2019].

${ }^{43}$ The 'return to the roots' movement appeared in the 1920s and focused on the redefinition of

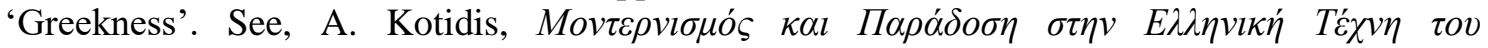

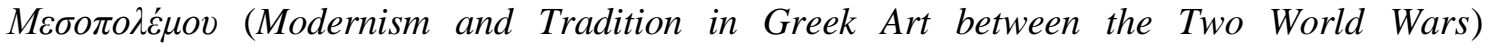
(Thessaloniki: University Studio Press, 1993).

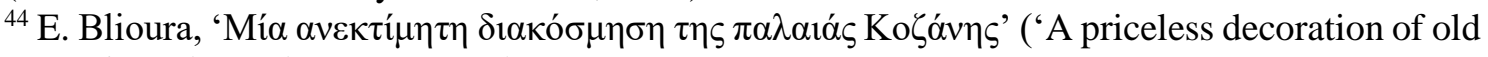
Kozani'), Elimeiaka, 59 (December 2007), pp. 175-184.

${ }^{45}$ A. Bounia, 'Public displays of private collections: Presenting the collection of Eleni Stathatos to the museum visitor,' in Narrating Objects, Collecting Stories, ed. by Sandra Dudley, Amy Barnes \& Jenny A. Walklate (London and New York: Routledge, 2012), pp. 237-254.

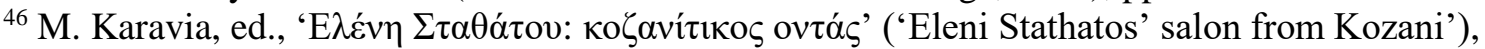

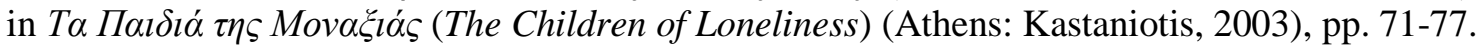

${ }^{47}$ Blioura, pp. 175-184.

${ }^{48}$ Personal communication with Eleni Merkati, Eleni Stathatos' granddaughter, 2016.

${ }^{49}$ See Bounia, 'Public displays of private collections', for a discussion of the network of Greek and international scholars around Eleni Stathatou.

${ }^{50}$ As per the museum label; see also, A. Delivorrias, Guide to the Benaki Museum (Athens: Benaki Museum, 2000), p. 109.

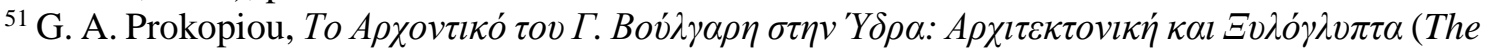
Mansion of G. Voulgaris in Hydra: Architecture and Woodcarvings) (Athens: Benaki Museum, 2001), p. 10.

${ }^{52}$ Delivorrias, p. 109

${ }^{53}$ Hatzimichali, p. 844.

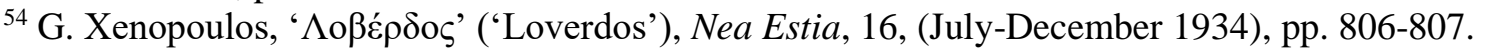

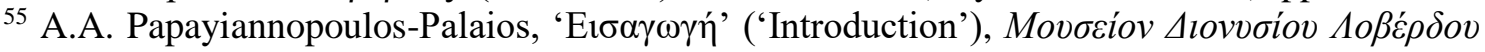
(Dionysios Loverdos’ Museum) (Athens: Dionysios Loverdos Museum, 1946), p. 8.

${ }^{56}$ Roupa.

${ }^{57}$ Artisans in Skyros produced carved wooden furniture whose style was believed to have originated in the Byzantine period. As a folklorist, Hatzimichali studied the traditional folk arts in Skyros and published her first book on this topic in 1927.

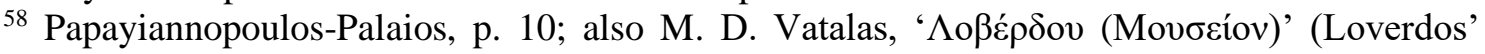

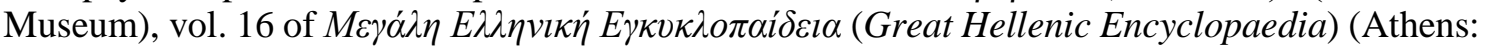
Pyrsos, 1926-1934), pp. 184-187.

59 The Hellenic Ministry of Culture recently (April 2020) approved the new museological arrangement of the Loverdos Museum.

${ }^{60}$ A. Higonnet, A Museum of One's Own (Pittsburgh: Periscope, 2009), p. xii.

${ }^{61}$ K. Kourelis 'Byzantine houses and modern fictions. Domesticating Mystras in 1930s Greece,' Dumbarton Oaks Papers, 65-66, (2011-2012), p. 322, p. 402ff.

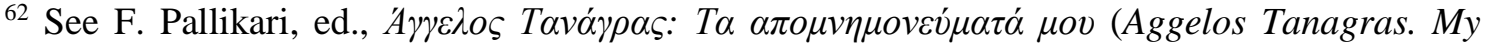
Memoirs) (Athens: n.p., 2016), p. 281-2, note 250.

${ }^{63}$ A. Tanagras, $O$ П $\check{\pi} \pi \lambda o \varsigma ~ \tau \eta \varsigma ~ I \sigma l \delta o \varsigma$ (The Veil of Isis) (Athens: Sideris, 1926), p. 38. 
${ }^{64}$ Tanagras, p. 39.

${ }^{65}$ Rhodes became part of Greece only after the Second World War in 1948, while Northern Greece (Epirus and Macedonia) became 'part of the national body' after the Balkan Wars in 19121913.

${ }^{66}$ K. Hill, 'Collecting authenticity,' Museum History Journal 4(2) (2011), p. 213.

${ }^{67}$ Hill, 'Collecting authenticity', p. 221.

${ }^{68}$ Hill, Women and Museums, p. 187.

${ }^{69}$ Ibid.

${ }^{70}$ A. Psarra and E. Fournaraki, 'Parren, Callirhoe (born Siganou) (1859-1940)' in F. DeHaan, A. Louifti, and K. Daskalova (eds), Biographical Dictionary of Women's Movements and Feminisms: Central, Eastern and South Eastern Europe, $19^{\text {th }}$ and $20^{\text {th }}$ centuries (New York: Central European University Press, 2006), 402-407.

${ }^{71}$ Higgonet, A Museum of One's Own, p. 157.

${ }^{72}$ Bounia, 'Public displays of private collections'.

${ }^{73}$ Ibid, p. 245.

${ }^{74}$ Ibid, pp. 245-6

${ }^{75}$ Papayiannopoulos-Palaios, pp. 7-8.

${ }^{76}$ Hill, Women and Museums.

${ }^{77}$ Hill, p. 7.

${ }^{78}$ Kourelis, 'Byzantium and the Avant-Garde', 406, note 70. On the use of period rooms in Greece, see Bounia, 'Exhibiting women's handicrafts'.

${ }^{79}$ The American School of Classical Studies had a similar influence. See Kourelis, 'Byzantium and the Avant-Garde'.

${ }^{80}$ Kourelis, 'Byzantine houses and modern fictions', p. 429. 